\title{
MANFAAT MANGROVE BAGI PERUNTUKAN SEDIAAN FARMASITIKA DI DESA MAMUYA KECAMATAN GALELA TIMUR KABUPATEN HALMAHERA TIMUR (TINJAUAN ETNOFARMAKOLOGIS)
}

\author{
Salim Abubakar ${ }^{1}$, Masykhur Abdul Kadir $^{1}$, Eko S. Wibowo ${ }^{2}$, \\ Nebuchadnezzar Akbar ${ }^{2}$ \\ ${ }^{1}$ Program Studi Manajemen Sumberdaya Perairan, FPIK, \\ Universitas Khairun, Ternate, Maluku Utara, Indonesia \\ ${ }^{2}$ Program Studi IImu Kelautan, FPIK, Universitas Khairun, Ternate, \\ Maluku Utara, Indonesia \\ Email: nezzarnebuchad@yahoo.co.id
}

Received February 2019, Accepted April 2019

\begin{abstract}
ABSTRAK
Penelitian ini dilakukan dengan tujuan untuk mengetahui jenis mangrove yang dimanfaatkan dalam pengobatan tradisional di Desa Mamuya Kecamatan Galela Timur, mengetahui bagian dari mangrove yang berpotensi untuk sediaan farmasitika dan mengetahui teknik pengolahan bahan mangrove yang dijadikan sebagai obat di Desa Mamuya Kecamatan Galela Timur. Hasil penelitian ditemukan jenis mangrove yang dimanfaatkan penduduk Desa Mamuya sebagai obat sebanyak 8 jenis yaitu Bruguiera gymnorrhiza, Rhizophora apiculata, R. stylosa, Sonneratia alba, Xylocarpus gratanum, Xylocarpus molucensis, Nypa fruticans dan Heritiera littoralis. Bagian mangrove yang dijadikan sebagai obat yaitu : akar muda, kulit batang, daun dan buah. Cara mengolah bahan dari bagian mangrove, akar, kulit batang, daun, buah dilakukan secara sederhana yaitu ada yang dilumatkan dalam mulut dan ada yang direbus. Masa penyembuhan ditentukan seberapa parah (akut) penyakit yang diderita.
\end{abstract}

Kata Kunci : Desa Mamuya, Etnofarmakologi, Farmasitika, Mangrove

\section{ABSTRACT}

BENEFITS OF MANGROVE FOR PHARMACITIC INVENTORY IN MAMUYA VILLAGE, EAST GALELA DISTRICT, EAST HALMAHERA REGENCY (ETHOPHARMACOLOGICAL REVIEW). This research was conducted to determine the type of mangrove used in traditional medicine in the village of Mamuya, Galela Timur District, knowing the potential part of the mangrove for pharmaceutical preparation and knowing the techniques for processing mangrove materials which were used as medicine in Mamuya Village, Galela Timur District. The results of the study 
found that the types of mangroves used by the residents of Mamuya Village were 8 types of drugs, namely Bruguiera gymnorrhiza, Rhizophora apiculata, $R$. stylosa, Sonneratia alba, Xylocarpus gratanum, Xylocarpus molucensis, Nypa fruticans and Heritiera littoralis. Parts of the mangrove that are used as medicine are: young roots, bark, leaves and fruit. How to process ingredients from parts of the mangrove, roots, bark, leaves, fruit is done simply that there are crushed in the mouth and some are boiled. The healing period is determined by how severe (acute) the disease is suffered.

Keywords : Mamuya Village, Ethnopharmacology, Pharmacy, Mangrove

\section{PENDAHULUAN}

Ekosistem mangrove merupakan suatu ekosistem peralihan antara darat dan laut (Abubakar et al., 2018). Ekosistem ini merupakan salah satu ekosistem pesisir yang memiliki fungsi ekologis dan ekonomis. Fungsi ekologis hutan mangrove antara lain pelindung garis pantai, mencegah intrusi air laut, habitat (tempat tinggal), tempat mencari makan (feeding ground), tempat asuhan dan pembesaran (nursery ground), serta tempat pemijahan (spawning ground) bagi berbagai biota perairan. Sedangkan fungsi ekonominya, antara lain penghasil keperluan rumah tangga, penghasil keperluan industri dan penghasil bibit serta sebagai bahan baku obat-obatan (Suryono, 2013). Ketersediaan ekosistem mangrove tentunya dapat mempengaruhi ketersediaan sumberdaya ikan, komunitas biota bentik dan menciptakan mata rantai didaerah sekitar (Akbar et al., 2018). Tumbuhan yang diduga kuat memiliki bahan bioaktif adalah mangrove. Mangrove dalam farmasitika mempunyai peranan penting karena mangrove dapat menghasilkan suatu obat yang memiliki kemampuan tersendiri yang dapat menyembuhkan suatu penyakit. Pemanfaatan tumbuhan mangrove untuk pengobatan tradisional berbagai penyakit telah dilakukan oleh masyarakat di daerah pesisir sejak dahulu secara turun temurun. Hal ini dapat dipahami karena mangrove dapat diperoleh dengan mudah dan teknik meramunya sangat sederhana. Biasanya bagian mangrove yang digunakan adalah pada bagian propagul (bakal tunas), daun dan batang (Purwanti, 2016).

Kenyataan bahwa suatu penyakit dapat disembuhkan dengan tumbuhan mangrove diungkapkan oleh masyarakat dan diwariskan dari generasi ke generasi, sehingga bahan dan cara pengobatan itu membudidaya di daerah tersebut dan tetap diyakini kebenarannya (merupakan pengalaman empiris). Meskipun secara ilmiah belum terbukti. Beberapa contoh khasiat mangrove untuk obat tradisional di wilayah Propinsi Maluku Utara berdasarkan studi etnofarmakologi yang dilakukan Abubakar (2011) adalah Rhizophora apiculata sebagai obat muntah, rematik dan nyeri otot, luka dalam, TBC dan luka baru. Sonneratia alba biasa digunakan oleh penduduk untuk mengobati nyeri otot, sakit pinggang, sakit tulang dan sakit persendiaan yang biasa disebut lusiang oleh penduduk Pulau Mantehage. Mangrove jenis Sonneratia ovata oleh 
penduduk setempat biasa digunakan untuk mengobati dan menghentikan pendarahaan pada luka atau sebagai aktivitas koagulasi pada darah.

Metode menemukan obat baru adalah dengan mempelajari pengobatan tradisional yaitu cara pengobatan yang dijalankan oleh sekelompok orang secara turun-temurun. Dengan penelitian lebih lanjut dapat diketahui apakah senyawa tersebut memiliki efek terapi atau hanya efek plasebo (Setiawan, 2018). Etnofarmakologis merupakan IImu khasiat obat atas dasar pengalaman pada masyarakat atau suku tertentu dalam pengobatan penyakit yang sudah dilakukan turun temurun. Farmakologi kelautan merupakan ilmu khasiat obat yang bahannya bersumber dari biota laut dan pesisir. Kajian etnofarmakologis juga mempelajari cara dan fungsi sistem hidup dipengaruhi obat tradisional. (Abubakar, 2008). Eksploitasi sumberdaya hayati hutan mangrove sebagian besar mengarah kepada pengelolaan untuk bahan industri yang bernilai ekonomis penting yaitu industri bahan bangunan dan keperluan bahan rumah tangga. Sedangkan pemanfaatan tumbuhan sebagai bahan industri farmasi masih sangat rendah. Hal ini disebabkan kurangnya penelitian yang dapat menyediakan informasi mengenai bahan bioaktif atau biotoksin dari tumbuhan mangrove yang dapat digunakan sebagai bahan sediaan obat.

\section{MATERI DAN METODE}

\section{Waktu dan Tempat Penelitian}

Penelitian dilaksanakan selama 6 bulan yaitu Mei-Oktober 2018 di Desa Mamuya Kecamatan Galela Kabupaten Halmahera Utara. Invetarisasi jenis mangrove di Desa Mamuya dilakukan dengan menggunakan metode survei jelajah yaitu mengamati jenis mangrove mulai dari zona depan sampai zona belakang. Untuk jenis mangrove yang dijadikan sebagai obat diambil bagian yang berpotensi dijadikan sebagai obat untuk selanjutnya dilakukan pengolahan.

\section{Metode Pengambilan Data}

Informasi tentang jenis-jenis mangrove yang digunakan masyarakat sebagai obat, maka pengambilan data dilakukan melalui in-depth interview secara PRA (Chambers 1996 dalam Abubakar. 2011) yaitu berpartisipasi langsung dengan masyarakat. Metode ini dilakukan untuk mendapatkan informasi teknik penggunaan bahan hayati untuk pengobatan dari jenisjenis mangrove yang ada dan secara langsung dapat berpartisipatif dengan masyarakat di Desa Mamuya.

Hasil informasi dari masyarakat yang terlibat langsung baik sebagai peramu obat maupun sebagai pengguna (orang yang sakit) selanjutanya dilakukan pengambilan bagian jenis mangrove yang digunakan sebagai obat bersama dengan peramu obat. Bagian jenis mangrove yang telah diambil selanjutnya dilakukan pengolahan bahan untuk semua jenis penyakit yang diderita dan langsung dilakukan pengobatan kepada responden yang mengalami sakit. 
Secara umum analisis data dilakukan secara deskriptif-kualitatif. Analisis ini didasarkan pada topik penelitian yang dipilih menyangkut identifikasi bahan-bahan hayati dari pesisir dan laut untuk keperluan pengobatan tradisonal.

\section{HASIL DAN PEMBAHASAN}

\section{Komposisi Jenis Mangrove}

Hasil penelitian, diperoleh komposisi jenis mangrove di Desa Mamuya sebanyak 6 famili dengan 8 jenis. Komposisi jenis mangrove yang ditemukan dapat dilihat pada (Tabel 1).

Tabel 1. Komposisi Jenis Mangrove di Desa Mamuya

\begin{tabular}{clll}
\hline No. & \multicolumn{1}{c}{ Famili } & \multicolumn{1}{c}{ Jenis } & Nama Lokal \\
\hline 1 & & Bruguiera gymnorrhiza & Guwoi \\
2 & Rhizophoraceae & $\begin{array}{l}\text { Rhizophora apiculata } \\
\text { Rhizophora stylosa }\end{array}$ & Los \\
3 & & Los \\
4 & Sonneratiaceae & Sonneratia alba & Gieg \\
5 & Meliaceae & Xylocarpus granatum & Lelim \\
6 & Xylocarpus mollucensis & Lelim \\
7 & Avicenniaceae & Avicennia alba & Kayu rica \\
8 & Arecaceae & Nypa fruticans & Bobo \\
9 & Sterculiaceae & Heritiera littoralis & Gifyol \\
\hline
\end{tabular}

Famili Rhizophoraceae memiliki jenis lebih banyak yaitu 3 jenis (Bruguiera gymnorrhiza, Rhizophora apiculata, Rhizophora stylosa) sedangkan famili Sonneratiaceae, Avicenniaceae, Arecaceae dan Sterculiaceae masing-masing hanya memiliki 1 jenis (Tabel 1).

Famili Rhizophoraceae tumbuh lebih banyak di Desa Mamuya disebabkan kondisi substrat di lokasi penelitian sangat mendukung pertumbuhan dari famili ini, seperti pasir, lumpur berpasir dan lumpur sebagai media tumbuh bagi famili ini. Abubakar dan Rina (2016) menyatakan bahwa pengaruh sifat tanah terhadap mangrove antara lain ditunjukkan oleh sebaran genus Rhizophora. Di daerah-daerah dengan tanah berlumpur dalam, Rhizophora mucronata merupakan vegetasi yang dominan, sedangkan daerah-daerah yang berlumpur dangkal didominasi oleh Rhizophora apiculata. Bila tanah banyak mengandung pasir atau karang maka Rhizophora stylosa yang mendominasi. Akbar et al (2017) mengatakan banyaknya jenis famili Rhizophoraceae yang ditemukan disebabkan kehadiran jenis ini setiap stasiun dan kuadran lebih banyak. Berdasarkan komposisi jenis mangrove yang ditemukan tersebut, hanya 8 jenis saja yang dimanfaatkan penduduk Tadupi sebagai obat yaitu Bruguiera gymnorrhiza, Rhizophora apiculata, R. stylosa, Sonneratia alba, Xylocarpus gratanum, Xylocarpus molucennsis, Nypa fruticans dan Heritiera littoralis. 


\section{Jenis dan Bagian Mangrove yang digunakan sebagai Obat}

Jenis mangrove yang digunakan sebagai obat tradisional di Desa Mamuya adalah 8 jenis yaitu: Sonneratia alba, Avicenia alba, Xylocarpus granatum, Rhizophora stylosa, Rhizophora apiculata dan Ceriops decandra. Sedangkan bagian mangrove yang digunakan sebagai obat yaitu: akar, kulit batang, daun dan buah/propagul (buah yang masih muda). Seperti halnya obat tradisional, maka obat yang bahan utamanya berasal dari mangrove ini adalah alami dan tidak mengandung efek samping.

Cara pengobatan yang dilakukan umumnya saat insidentil, misalnya luka kena benda tajam, juga kalau dalam tubuh mulai terasa ada kelainan. Secara lengkap, khasiat jenis mangrove yang ditemukan, serta taksonominya (Tabel 2).

Tabel 2. Khasiat Mangrove Sebagai Obat di Desa Mamuya

\begin{tabular}{|c|c|c|c|}
\hline Vegetasi & Jenis & Bagian Tanaman & $\begin{array}{l}\text { Khasiat } \\
\text { Pengobatan }\end{array}$ \\
\hline Pohon & $\begin{array}{l}\text { Bruguiera } \\
\text { gymnorrhiza }\end{array}$ & Buah (Propagul) & $\begin{array}{l}\text { Mangir (jamur di } \\
\text { lidah) } \\
\text { Pencuci perut bayi. } \\
\text { Kulit gatal-gatal }\end{array}$ \\
\hline Pohon & $\begin{array}{l}\text { Rhizophora } \\
\text { apiculata }\end{array}$ & $\begin{array}{l}\text { Kulit batang, akar muda, } \\
\text { daun }\end{array}$ & $\begin{array}{l}\text { Mangir (jamur di } \\
\text { lidah) } \\
\text { Luka baru } \\
\text { Gigi Sakit } \\
\text { Lusiang } \\
\text { Liver } \\
\text { Kulit gatal-gatal }\end{array}$ \\
\hline Pohon & $\begin{array}{l}\text { Rhizophora } \\
\text { stylosa }\end{array}$ & $\begin{array}{l}\text { Kulit batang, akar muda, } \\
\text { daun }\end{array}$ & $\begin{array}{l}\text { Mangir (jamur di } \\
\text { lidah) } \\
\text { Luka baru } \\
\text { Gigi sakit } \\
\text { Lusiang } \\
\text { Liver } \\
\text { Kulit gatal-gatal }\end{array}$ \\
\hline Pohon & $\begin{array}{l}\text { Sonneratia } \\
\text { alba }\end{array}$ & $\begin{array}{l}\text { Buah muda, } \\
\text { batang, akar }\end{array}$ & $\begin{array}{l}\text { Mangir } \\
\text { Nafsu makan } \\
\text { Lusiang (nyeri otot, } \\
\text { sakit pinggang, } \\
\text { sakit tulang, } \\
\text { rematik) } \\
\text { Malaria } \\
\text { Memulihkan } \\
\text { stamina } \\
\text { Usus buntu, liver }\end{array}$ \\
\hline
\end{tabular}




\begin{tabular}{|c|c|c|c|}
\hline Pohon & $\begin{array}{l}\text { Xylocarpus } \\
\text { granatum }\end{array}$ & $\begin{array}{l}\text { Kulit batang dan buah } \\
\text { (tua) }\end{array}$ & $\begin{array}{l}\text { Memulihkan } \\
\text { stamina ibu } \\
\text { melahirkan } \\
\text { Sakit perut } \\
\text { Liver } \\
\text { Bedak }\end{array}$ \\
\hline Pohon & $\begin{array}{l}\text { Xylocarpus } \\
\text { molucensis }\end{array}$ & $\begin{array}{l}\text { Kulit batang dan buah } \\
\text { (tua) }\end{array}$ & $\begin{array}{l}\text { Memulihkan } \\
\text { stamina ibu } \\
\text { melahirkan } \\
\text { Sakit perut } \\
\text { Liver } \\
\text { Bedak }\end{array}$ \\
\hline Pohon & $\begin{array}{l}\text { Nypa } \\
\text { fruticans }\end{array}$ & Tangkai daun muda & Luka baru \\
\hline Pohon & $\begin{array}{l}\text { Heritiera } \\
\text { littoralis }\end{array}$ & Kulit batang & $\begin{array}{l}\text { Memulihkan } \\
\text { stamina ibu } \\
\text { melahirkan } \\
\text { Liver }\end{array}$ \\
\hline
\end{tabular}

Penggunaan jenis dan bagian mangrove untuk pengobatan bervariasi tergantung penyakit yang diderita. Untuk penyakit mangir (jamur di lidah) pada anak-anak balita dapat digunakan jenis Bruguiera gymnorrzhiza (buah/propagul), Rhizophora apiculata dan R. stylosa (akar muda) dan Sonneratia alba (buah muda). Pengobatan luka baru saat terkena benda tajam digunakan jenis Rhizphora stylosa dan $R$. apiculata (akar muda) dan Nypa fruticans (ujung daun muda). Jenis penyakit gigi sakit dapat digunakan hasil rebusan dari kulit batang dan daun dari jenis Rhzophora apiculata dan R. stylosa.

Untuk pengobatan lusiang (nyeri otot, sakit pinggang, sakit tulang, rematik), nafsu makan, malaria, memulihkan stamina digunakan kulit batang Rhizphora apiculata, $R$. stylosa dan Sonneratia alba. Sedangkan untuk memulihkan stamina ibu melahirkan, sakit perut, liver, digunakan kulit batang Xylocarpus granatum, $X$. molucensisi dan Heriteria littoralis. Buah dari Xylocarpus $s p$ dapat juga digunakan sebagai bedak untuk mempercantik wajah. Untuk penyakit gatal-gatal digunakan daun dan kulit batang Brugueira gymnorrhiza, Rhizophora apiculata $R$. stylosa. Sedangkan untuk penyakit usus buntu dapat digunakan akar Sonneratia alba.

Bagian jenis mangrove yang digunakan sebagai bahan obat hampir sama untuk semua wilayah. Seperti hasil penelitian Abubakar (2011) di wilayah Provinsi Maluku Utara dan Purwanti (2016) di Provinsi Sulawesi Selatan, bahwa bagian jenis mangrove digunakan sebagai obat yaitu buah, batang, akar dan daun sebagai. Selanjutnya Noor dkk (2015) menyatakan bahwa mangrove yang digunakan sebagai bahan obatobatan berasal dari buah, daun, kulit batang dan akar mangrove.

Cara penyembuhan gejala atau penyakit melalui pengetahuan lokal ini telah diketahui turun-temurun. Penduduk Desa Mamuya yang ditemui 
mengetahui jenis-jenis mangrove yang memiliki khasiat untuk obat-obatan. Kemungkinan pengetahuan lokal jenis mangrove yang digunakan penduduk Desa Mamuya untuk pengobatan antara lain, karena dahulu kala agak sulit mencari pertolongan/pengobatan di ibu kota kabupaten dan minimnya pendapatan masyarakat untuk berobat ke dokter atau rumah sakit. Bila ada penduduknya yang terkena musibah/penyakit, cara yang paling mudah untuk pertolongan pertama dengan memanfaatkan obatobatan tradisional.

Hasil penelitian ini bila dibandingkan dengan hasil peneitian yang telah dilakukan baik dalam wilayah Maluku Utara maupun oleh Abubakar (2008) di Desa Tadupi dan Madjowa (1998) di Pulau Mantehage Manado, khasiat jenis mangrove yang digunakan sebagai obat hampir sama yaitu Rhizophora $s p$ dan Bruguiera gymnorrizha sebagai luka baru, obat muntah, rematik dan nyeri otot, luka dalam, TBC dan mangir di lidah. Sonneratia alba biasa digunakan oleh penduduk untuk mengobati nyeri otot, luka baru, sakit pinggang, sakit tulang dan sakit persendiaan yang biasa disebut lusiang oleh penduduk. Daun muda jenis Nypa fruticans oleh penduduk setempat biasa digunakan untuk mengobati dan menghentikan pendarahaan pada luka atau sebagai aktivitas koagulasi pada darah.

Namun ada bagian jenis mangrove yang digunakan di Desa Mamuya tetapi tidak ditemukan di Desa Tadupi seperti pengobatan usus buntu menggunakan akar Sonneratia alba dan penyakit gigi sakit dengan menggunakan hasil rebusan batang dan daun dari Rhizophora apiculata, $R$. stylosa dan Brugueira gymnorrhiza. Untuk pengobatan luka baru dan menghentikan darah dari jenis Nypa fruticans sudah dibuktikan secara laboratorium oleh Abubakar (2011) dalam kajian Uji Aktivitas Antikoagulasi Dan Pengaruhnya Terhadap Darah Manusia Dari Ekstrak Nypah (Nypah fruticans) Di Desa Tuada. Hasil yang diperoleh menggunakan ekstrak dari jenis ini lebih cepat menghetikan darah serta tidak mengandung racun. Dahuri $d k k$ (2001), menyatakan bahwa mangrove merupakan salah satu vegetasi pantai tropis yang di duga memiliki unsur-unsur bioaktif. Dalam ilmu farmasitika mangrove mempunyai peranan penting karena mangrove dapat menghasilkan suatu obat yang memiliki keampuhan tersendiri yang dapat menyembuhkan suatu penyakit.

Bandaranayake (1998) dalam Mardiansyah dan Bahri (2016) menyatakan bahwa hutan mangrove di Indonesia telah lama dikenal penduduk sebagai sumber dari berbagai bahan pangan, bahan bangunan, kayu bakar, zat warna dan obat-obatan tradisional. Mangrove (buah, daun, batang, kulit batang dan akar) secara medis digunakan untuk mengobati asma, diabetes, rematik, hepatitis, penyakit kulit, penangkal racun ular, leukemia, kanker, penyakit mata, tumor, kolera, malaria, disentri, demam, analgesik, antiseptik dan sebagai antibiotik. 


\section{Teknik Pengolahan Bahan Alami}

Teknik pengolahan bahan alami masing-masing jenis mangrove yang digunakan sebagai obat yaitu :

\section{a. Bruguiera gymnorrhiza}
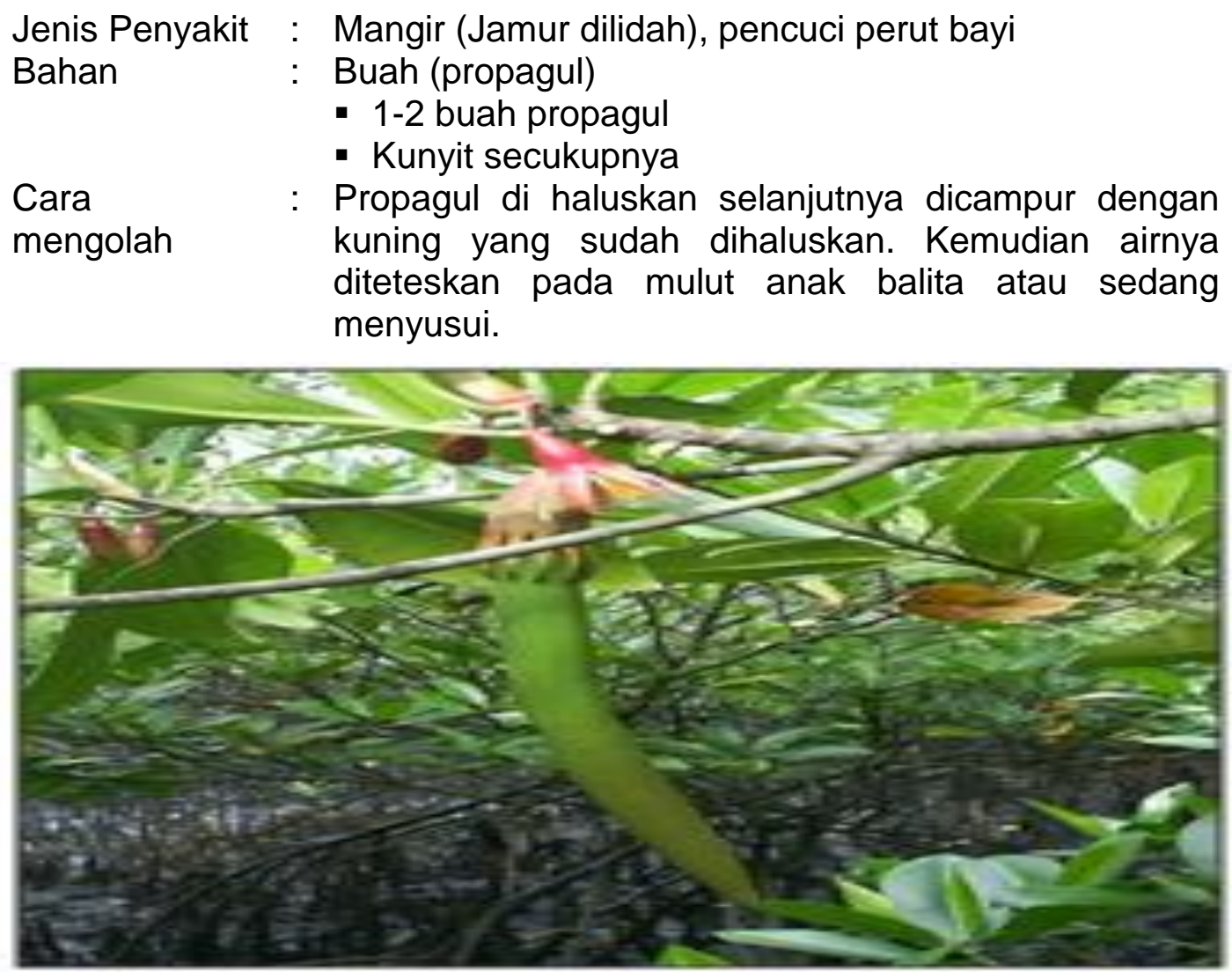

Gambar 1. Bagian Bruguiera gymnorrhiza yang dijadikan obat (Buah)

\section{b. Rhizopora apiculata dan Rhizophora stylosa}

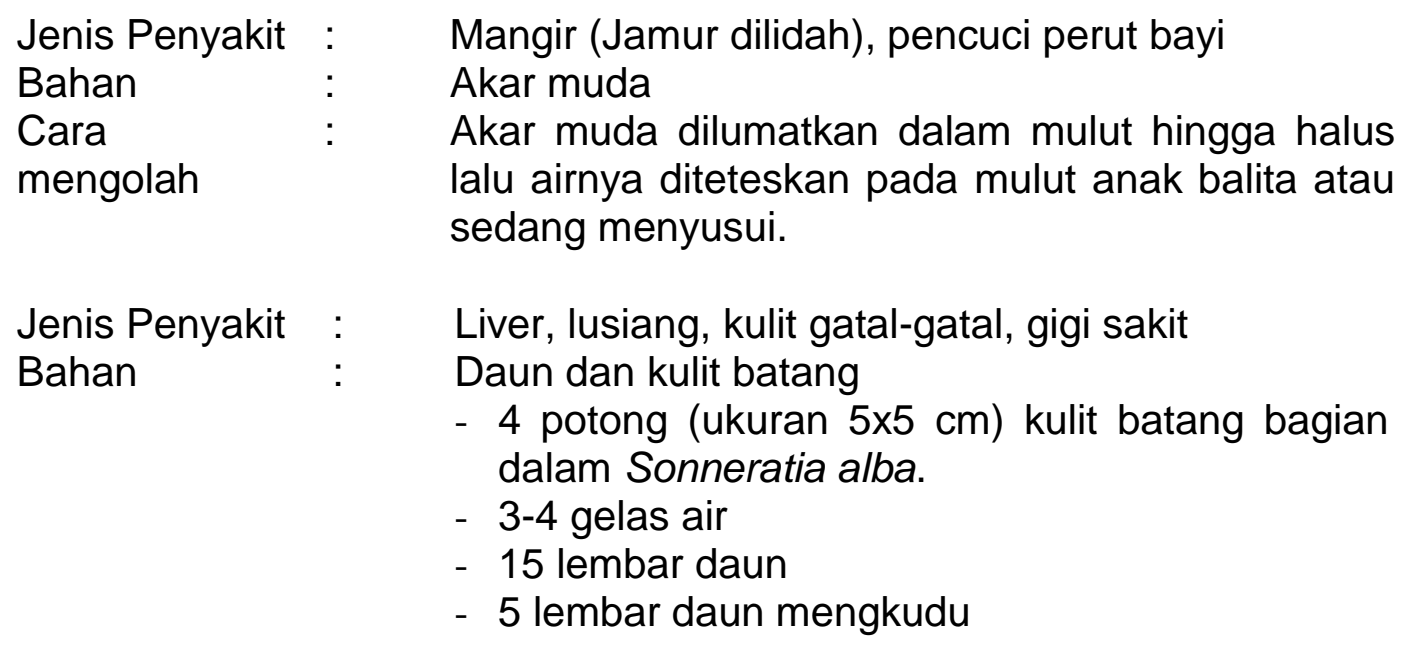


Cara mengolah

Jenis penyakit
Bahan
Cara
mengolah

- Penyakit liver dan lusiang, semua jenis bahan dicampur menjadi satu kemudian direbus sampai mendidih ( $\pm 1 / 2$ gelas air sisa rebusan). Minum selagi hangat dan dilakukan setiap pagi dan sore.

- Kulit gatal-gatal ambil air dan daun hasil rebusan baru digosok dibagian yang gatal.

- Gigi sakit, air rebusan di kumur.

Luka baru

Buah (propagul)

- 4-5 buah propagul

- Propagul dihaluskan dan diletakkan di atas luka.

- Darah akan terhenti. Lakukan 2-3 hari sampai luka sembuh.

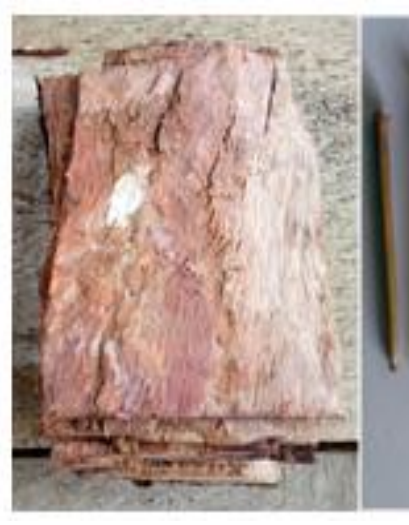

Kulit batang

Akar muda

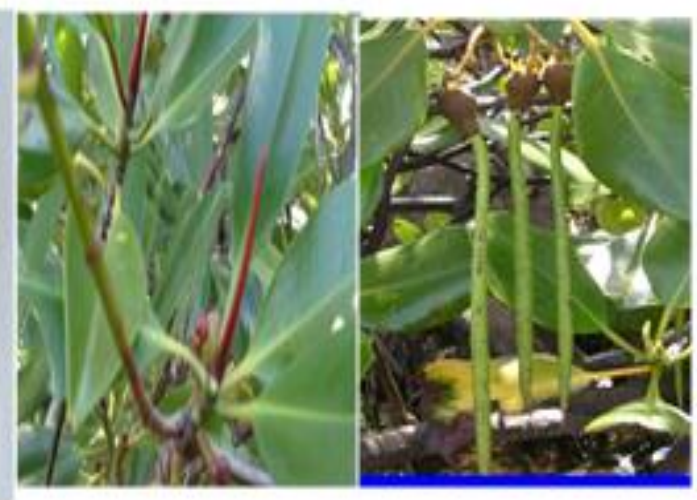

Buah

Gambar 2. Bagian Rhizophora apiculata dan $R$. stylosa yang dijadikan sebagai obat

\section{c. Sonneratia alba}

Jenis Penyakit : Mangir (Jamur dilidah), pencuci perut bayi

Bahan : - Buah muda (7 buah yang belum mekar) - Daun

Jenis Penyakit : Liver, lusiang, memulihkan ibu setelah melahirkan,
Bahan : Kulit batang 4 potong (ukuran $5 \times 5 \mathrm{~cm}$ ) kulit batang bagian dalam Sonneratia alba.

Cara mengolah

: Semua jenis bahan dicampur menjadi satu kemudian direbus sampai mendidih $( \pm 1 / 2$ gelas air sisa rebusan). Minum selagi hangat dan dilakukan setiap pagi dan sore.

Jenis Penyakit : Usus buntu

Bahan : 7 buah akar muda 
Cara : Direbus sampai mendidih $( \pm 1 / 2$ gelas air sisa mengolah rebusan). Minum selagi hangat dan dilakukan setiap pagi, siang dan sore.

Jenis Penyakit : Gigi sakit

Bahan : - 5 potong kulit batang dengan ukuran $5 \times 5 \mathrm{~cm}$

- Akar durian (5 potong)

- Kulit pohon langsat (5 potong_.

Cara : Semua bahan dicampur dan direbus sampai mendidih mengolah ( $\pm 1 / 2$ gelas air sisa rebusan). Minum selagi hangat dan dilakukan setiap pagi, siang dan sore.
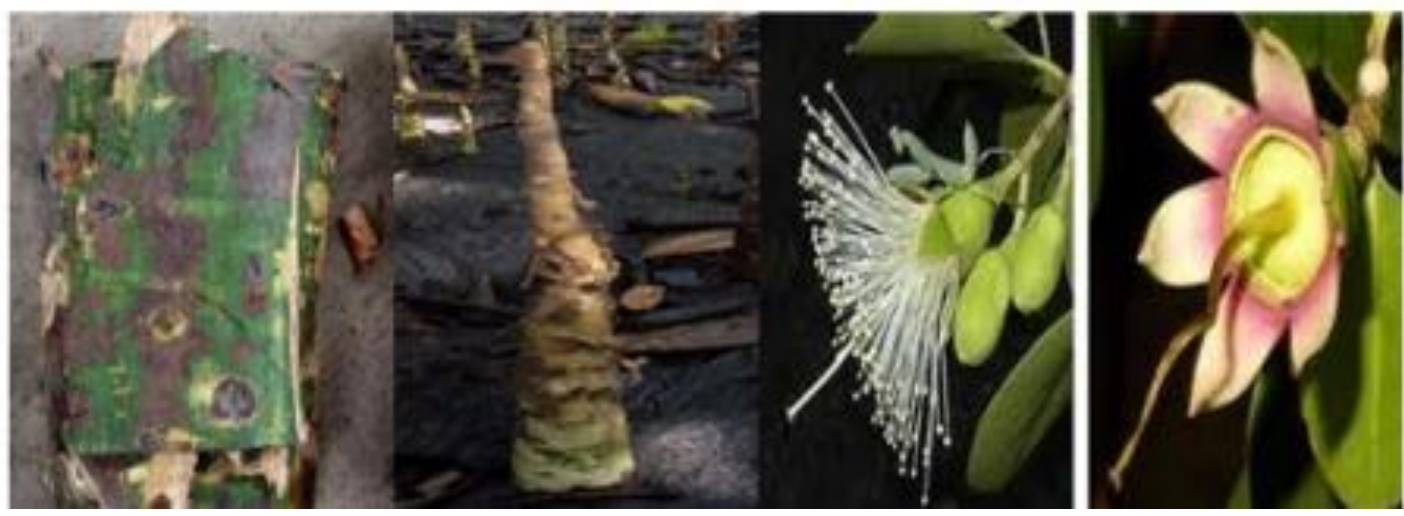

Kulit batang

Akar

Buah muda/propagul

Gambar 3. Bagian Sonneratia alba yang dijadikan sebagai obat

d. Xylocarpus granatum, Xylocarpus molucensis

Jenis Penyakit : Memulihkan stamina ibu melahirkan, sakit perut dan liver

Bahan : - 5 potong (ukuran $5 \times 5 \mathrm{~cm}$ ) kulit batang bagian dalam Xylocarpus granatum.

- 3 potong kulit batang kayu besi.

- 3 potong kulit batang Heriteria littoralis.

Cara : Semua bahan dicampur dan direbus sampai mendidih mengolah $\quad( \pm 1 / 2$ gelas air sisa rebusan $)$. Minum selagi hangat dan dilakukan setiap pagi, siang dan sore.

Jenis Penyakit : Wajah kusam

Bahan : - Buah (yang sudah tua) diambil bijinya sebanyak 46 biji.

- 3 genggam beras

Cara mengolah

: Semua bahan dicampurkan dan digiling sampai halus, selanjutnya ditambahkan sedikit air. Langsung dipakai pada wajah. 


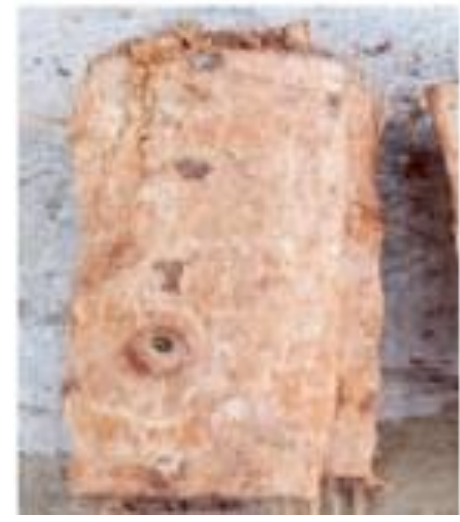

Kulit batang

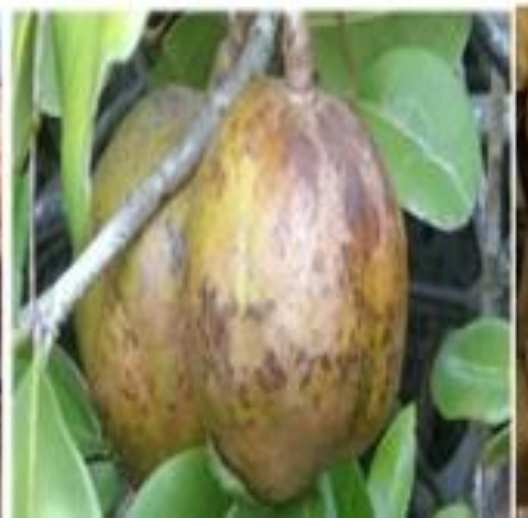

Buah

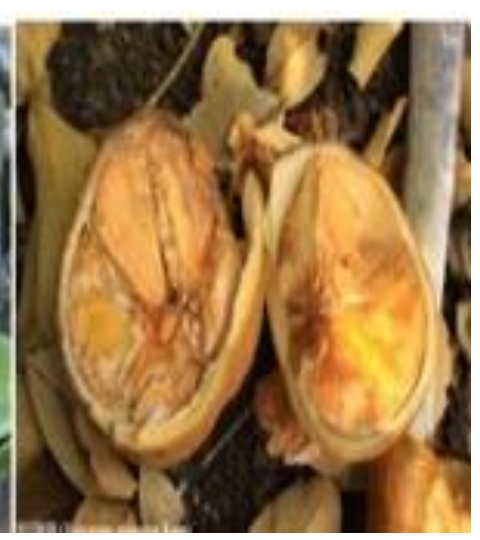

Biji

Gambar 4. Bagian Xylocarpus granatum dan $X$. molucensis yang dijadikan sebagai obat

\section{e. Nypa fruticans}

Jenis Penyakit : Luka baru/menghentikan darah

Bahan

: 1 helai daun tangkai muda Nypa fruticans.

Cara

mengolah

: Daun tangkai muda tersebut dihaluskan kemudian diletakkan pada luka. Darah akan terhenti seketika.
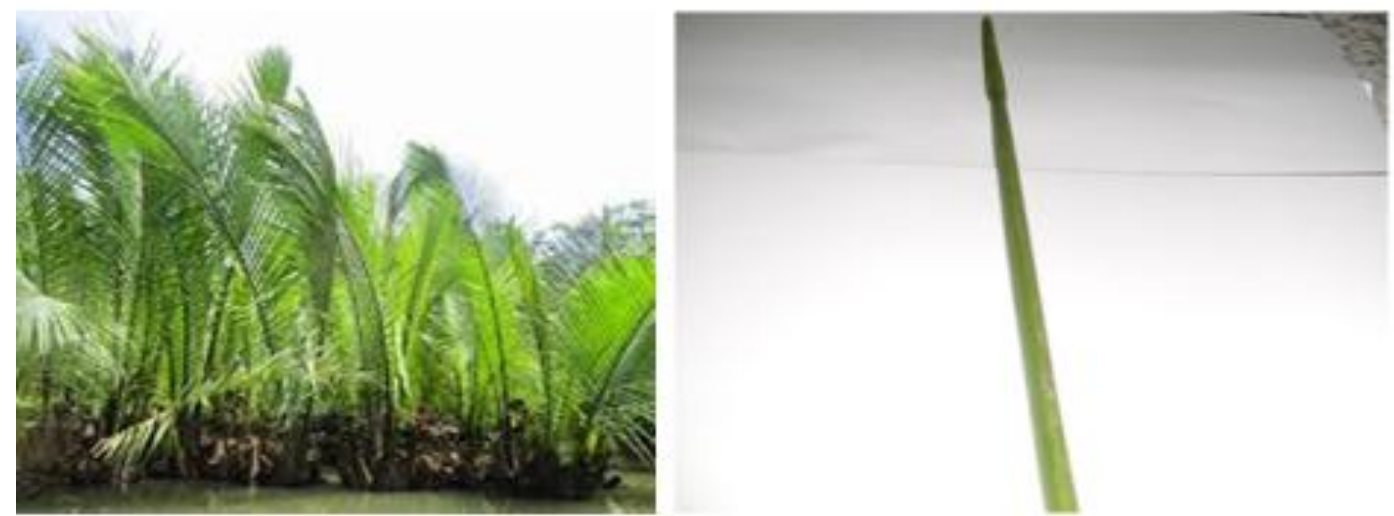

Gambar 5. Bagian Nypa fruticans yang dijadikan sebagai obat (pucuk daun)

\section{f. Heritiera littoralis}

Jenis Penyakit : Memulihkan stamina ibu melahirkan dan liver Bahan

: Kulit batang

- 5 potong (ukuran $5 \times 5 \mathrm{~cm}$ ) kulit batang bagian dalam Heritiera littoralis.

- 3 potong (ukuran $5 \times 5 \mathrm{~cm}$ ) kulit batang bagian dalam Xylocarpus granatum.

- 3 potong (ukuran $5 \times 5 \mathrm{~cm}$ ) kulit batang bagian dalam Sonneratia alba. 
Cara mengolah
: Semua jenis bahan dicampur menjadi satu kemudian direbus sampai mendidih ( \pm 3 gelas air sisa rebusan). Dinginkan selanjutnya di minum 2 kali sehari.

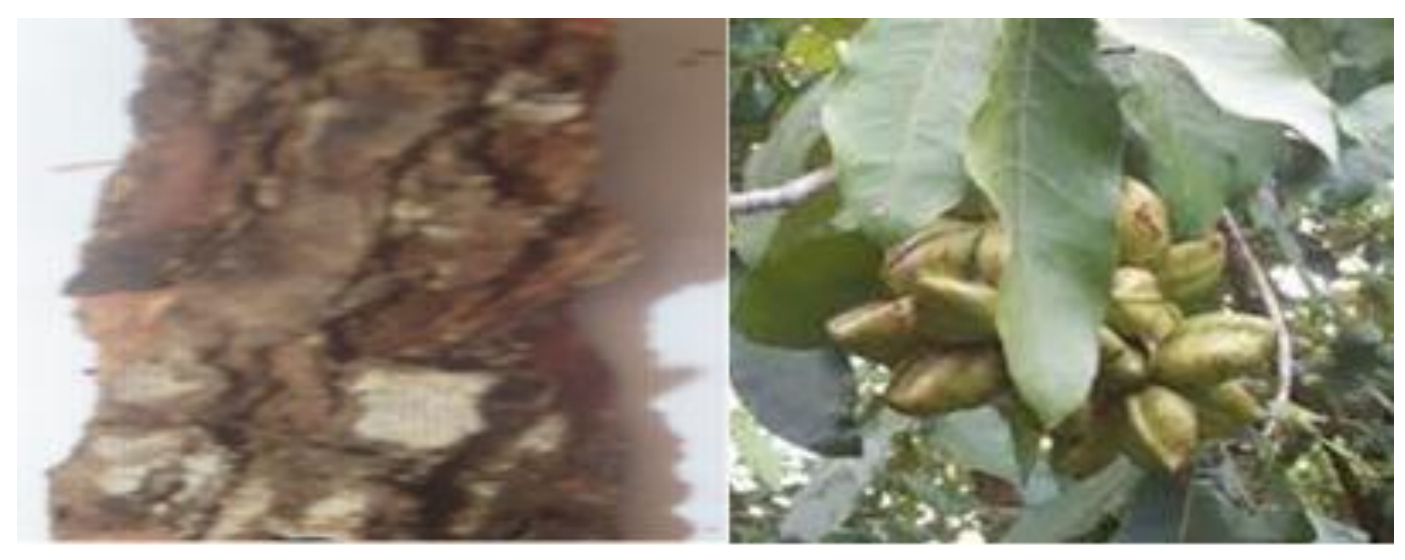

Gambar 6. Bagian Heritiera littoralis yang dijadikan sebagai obat (Kulit batang)

\section{Masa Penyembuhan}

Hasil penelitian yang dilakukan, masa penyembuhan pada masingmasing penyakit tergantung seberapa parah (akut) yang diderita. Studi kasus penyakit mangir (jamur di lidah) setelah diteteskan kedalam mulut balita langsung terasa khasiatnya, seperti bayi akan minum ASI lagi. Sedangkan untuk gejala penyakit lusiang (rematik, nyeri otot, sakit tulang dan persendian), sakit gigi dan memulihkan ibu setelah melahirkan setelah ramuannya diminum, reaksi obat akan terasa setelah satu atau dua jam. Karena itu, yang meminum obat ini disarankan istirahat. Tubuh yang terasa sakit akan normal kembali beberapa saat kemudian. Obat ini juga dapat diminum seminggu sekali atau dua kali untuk mempertahankan kondisi tubuh apabila bekerja siang dan malam.

Pengobatan penyakit malaria dan liver harus diminum dua atau tiga kali sehari sampai sembuh, dan biasanya sebulan penyakit liver akan segera sembuh dan seminggu untuk penyakit malaria. Sedangkan untuk luka baru, manfaat yang dirasakan langsung, dimana darah yang keluar bisa terhenti. Obat luka ini penting juga untuk pertolomgan pertama terutama saat berada di laut atau tempat yang agak jauh dari perkampungan tetapi berdekatan dengan pohon mangrove. Penyakit gatal-gatal langsung terasa khasiatnya setelah digosok dengan menggunakan daun dan air hasil rebusan yang masih hangat dan gejala gatal akan berkurang. Ini dilakukan setiap 2 kali sehari (pagi dan sore) sampai sembuh. Untuk penyakit usus buntu air hasil rebusan dimimum selagi hangat dan dilakukan 3 kali sehari (pagi, siang, malam). Penyakit akan sembuh selama 1-2 bulan yang ditandai tidak sakit lagi dibagian usus. Semua responden yang mengetahui cara penggunaan jenis-jenis mangrove untuk obat-obatan tidak pernah mengeluh atau merasa ada kelainan dalam sistem jaringan tubuh setelah memanfaatkan obat/ramuan 
tersebut. Bila ada keluarga yang sakit atau gejala sakit, akan diobati dengan cara seperti itu. Menurut responden khususnya lusiang, obat dari kulit batang mangrove reaksinya lebih terasa dibandingkan dengan obat rheumatic yang sudah dijual bebas di kios-kios.

Implimentasi pengobatan tradisional yang menggunakan ramuan tradisional, efek plasebo akan berperan di samping peran efek farmakologik dari bahan obat tradisional yang belum teridentifikasi. Dalam farmakologi yang dimaksud dengan plasebo adalah preparat obat yang tidak mengandung bahan berkhasiat, atau mengandung bahan obat tapi tidak memiliki efek terhadap keluhan atau gejala penyakit yang diobati (Moningka. 1997 dalam Abubakar. 2011). Suatu zat yang potensial memiliki efek terapi baru melewati serangkaian pengujian sebelum digunakan di klinik. Pemeriksaan itu meliputi skrining, uji pra klinik dan uji klinik. Salah satu cara untuk menemukan obat baru adalah dengan mempelajari pengobatan tradisional yaitu cara pengobatan yang dijalankan oleh sekelompok orang secara turun-temurun. Penelitian lebih lanjut dapat diketahui apakah senyawa tersebut memiliki efek terapi atau hanya efek plasebo (Setiawan. 1980 dalam Abubakar. 2008).

\section{KESIMPULAN}

Kesimpulan Berdasarkani hasil penelitian yaitu jenis mangrove yang dimanfaatkan penduduk Desa Mamuya sebagai obat sebanyak 8 jenis yaitu Bruguiera gymnorrhiza, Rhizophora apiculata, $R$. stylosa, Sonneratia alba, Xylocarpus gratanum, Xylocarpus molucensis, Nypa fruticans dan Heritiera littoralis. Bagian mangrove yang dijadikan sebagai obat yaitu : akar muda, kulit batang, daun dan buah. Cara mengolah bahan dari bagian mangrove, akar, kulit batang, daun, buah dilakukan secara sederhana yaitu ada yang dilumatkan dalm mulut dan ada yang direbus. Masa penyembuhan ditentukan seberapa parah (akut) penyakit yang diderita.

\section{UCAPAN TERIMAKASIH}

Penulis mengucapkan terimakasih kepada Fakultas Perikanan dan

Ilmu Kelautan, Universitas Khairun, Ternate yang telah memberikan kesempatan untuk memperoleh bantun penelitian mandiri.

\section{DAFTAR PUSTAKA}

Abubakar, S. 2008. Studi Awal Etnofarmakologis Mangrove Bagi Peruntukan Sediaan Farmasitika di Desa Tadupi Kecamatan Oba Kota Tidore Kepulauan. Hasil Penelitian Dosen Muda. LPPM. Universitas Khairun. Ternate.

Abubakar, S. 2011. Pemanfaatan Mangrove Bagi Peruntukan Sediaan Farmasitika (Suatu Studi Etnofarmakologis) Di Desa Lola Kecamatan Oba Kota Tidore Kepulauan. Jurnal Vegetasi Biologi, 1 (2) : 73-83. 
Abubakar, S dan Rina. 2016. Analisis Kesesuaian Lahan Rehabilitasi Berdasarkan Tinjauan Tipologi Pantai di Desa Guraping Kecamatan Oba Utara Kota Tidore Kepulauan. Hasil Penelitian. Lembaga Penelitian dan Pengabdian Pada Masyarakat. Universitas Khairun. Ternate.

Abubakar S, Kadir MA, Akbar A, Tahir I. 2018. Asosiasi dan Relung Mikrohabitat Gastropoda Pada Ekosistem Mangrove Di Pulau Sibu Kecamatan Oba Utara Kota Tidore Kepulauan Provinsi Maluku Utara. Jurnal Enggano 3 (1): 22-38.

Akbar N, Marus I, Haji I, Abdullah S, Umalekhoa S, Ibrahim FS, Ahmad A, Ibrahim A, Kahar A, Tahir I. 2017. Struktur Komunitas Hutan Mangrove di Teluk Dodinga, Kabupaten Halmahera Barat Provinsi Maluku Utara. Jurnal Enggano, 2 (1) : 78-89.

Akbar N, Ibrahim A, Haji I, Tahir I, Ismail F, Ahmad M, Kotta R. 2018. Struktur Komunitas Hutan Mangrove di Desa Tewe, Kecamatan Jailolo Selatan, Kabupaten Halmahera Barat. Provinsi Maluku Utara. Jurnal Enggano, 3 (1) : 81-97.

Dahuri, R. J, Rais, S.P. Ginting dan M.J. Sitepu. 2001. Pengelolaan Sumberdaya Wilayah Pesisir dan Lautan Secara Terpadu. PT. Pradnya Paramita. Jakarta.

Madjowa,V. 1998. Manfaat Mangrove Bagi Peruntukan Sediaan Farmasitika, Studi Etnofarmakologis. Hasil Penelitian. FPIK UNSRAT. Manado.

Mardiansyah, S. Bahri. 2016. Potensi Tumbuhan Mangrove Sebagai Obat Alami Antimikroba Patogen. Jurnal Sainstech Farma, 9 (1) : 25-29.

Noor, Y. R, M. Khazali dan I.N.N. Suryadipura. 2015. Panduan Mengenai Hutan Mangrove di Indonesia. Ditjen PKA. Jakarta.

Purwanti, R. 2016. Studi Etnobotani Pemanfaatan Jenis-Jenis Mangrove Sebagai Tumbuhan Obat di Sulawesi. Prosiding Seminar Nasional Tumbuhan Obat Indonesia Ke-50, Samarinda, 20 - 21 April 2016.

Setiawan A. 2018. Pengobatan Tradisional di Desa Lemahabang Kulon, Kecamatan Lemahabang. Kabupaten. Cirebon. Jurnal Patanjala, 10 (1) ; 83-98.

Suryono, A. 2013. Sukses Usaha Pembibitan Mangrove Sang Penyelamat Laut. Penerbit Pustaka Baru Press. Yogyakarta. 